PROCEEDINGS OF THE

SEVENTEENTH INTERNATIONAL

MACHINE TOOL DESIGN AND RESEARCH

CONFERENCE 
PROCEEDINGS OF THE

\title{
SEVENTEENTH INTERNATIONAL MACHINE TOOL DESIGN AND RESEARCH CONFERENCE
}

\author{
held in Birmingham \\ 20th - 24th September, 1976
}

\author{
Edited by \\ S. A. TOBIAS \\ Chance Professor and Head of Department \\ Department of Mechanical Engineering \\ University of Birmingham
}

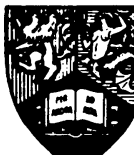

DEPARTMENT OF MECHANICAL ENGINEERING, THE UNIVERSITY OF BIRMINGHAM

in association with

$\mathrm{M}$

Macmillan Education 
(C) The Department of Mechanical Engineering, University of Birmingham 1977

Softcover reprint of the hardcover 1st edition 1977 978-0-333-21777-1

All rights reserved. No part of this publication may be reproduced or transmitted, in any form or by any means, without permission.

First published 1977 by

The Department of Mechanical Engineering, University of Birmingham,

P. O. Box 363, Birmingham, B 15 2TT, U. K.

in association with

The Macmillan Press Ltd

London and Basingstoke

Associated companies in New York, Dublin,

Melbourne, Johannesburg and Madras

\section{ISBN 978-1-349-81486-2 ISBN 978-1-349-81484-8 (eBook)}

DOI 10.1007/978-1-349-81484-8

Published in the U.S. A. by

Halsted Press, a Division of

John Wiley and Sons, Inc., New York

ISBN 978-0-470-99076-6

Library of Congress Catalog Card No : 77-70170

Produced in the City of Oxford by Oxprint Limited 


\title{
Seventeenth International Machine \\ Tool Design and Research Conference \\ 20th - 24th September, 1976
}

\author{
CONFERENCE ORGANIZING COMMITTEE \\ Chairman: Professor S. A. Tobias
}

\author{
POLICY COMMITTEE \\ Professor J. M. Alexander (ICST) Professor B. J. Davies (UMIST) \\ Professor W. Johnson (Cambridge) Emeritus Professor F. Koenigsberger (UMIST)
}

\section{ORGANIZING AND REVIEWING COMMITTEE}

\author{
Professor G. W. Rowe \\ Dr. B. F. Scott \\ E. Amini \\ Dr. M. K. Das \\ Dr. R. Davies \\ T. A. Dean \\ Dr. H. Kaliszer \\ Dr. W. A. Knight \\ A. W. Kwiatkowski \\ I. S. Morton \\ Dr. B. W. Rooks \\ Dr. M. M. Sadek \\ Dr. A. A. Shumsheruddin \\ Dr. C. E. N. Sturgess \\ Dr. S. Taylor \\ J. Trmal \\ H. S. Royce
}




\title{
CONTENTS
}

\author{
OPENING SESSION
}

Opening address PROFESSOR SIR SAM EDWARDS, F.R.S.

\section{CAD AND CAM}

The production of spiral bevel gears by computer aided manufacturing techniques. D. FRENCH and A. FERREIRA

The computer aided design and manufacture of vehicle lamps, M. F. HESSEY and J. N. S. DEANE

Design for numerically controlled manufacture of patterns and dies. T. H. GOSSLING and D. B. WELBOURN

\section{NC, CNC AND DNC}

Memory gives simple NC a new lease of life. G. C. KEAN

NC-technique for small batches. DIPL.-ING HÖRST GOHREN

Direct digital control for turning operations. M. WECK, K. SCHÄFER

Geometrical adaptive control in profile milling by CNC system. YOSHIHARU NAMBA and HIDEO TSUWA

Computer controlled profile jig grinding. A. A. SHUMSHERUDDIN

Adaptively controlled fully automatic balancing system. G. TRMAL and H. KALISZER

Improvement of working accuracy of a machining center by computer control compensation. TOSHIO SATA, YOSHIMI TAKEUCHI and NOBUYUKI OKUBO

\section{METAL CUTTING AND TOOL WEAR}

A comprehensive literature survey of chip control in the turning process.

\section{B. WORTHINGTON}

Characteristics of cutting force in plain milling operation using a helical cutter. SHINOBO KATO, TOSHIKATSU YAMADA, MASATOSHI HASHIMOTO and HIROSHI FUJII

Applications of a rotary turning tool. R. M. THOMAS and R. L. J. LAWSON

A study of bandsaw blade wear and its effects on cutting rates and economics. R. W.

TAYLOR and P. J. THOMPSON

An approach to on-line measurement of tool wear by spectrum analysis. A. DEL TAGLIA, S. PORTUNATO and P. TONI

Tool requirements for interrupted cutting. T. N. LOLADZE, G. N. TKEMALADZE, F. G. TOTCHIEV, A. I. MIKANADZE and O. V. KHOTCHIASHVILI

\section{GRINDING}

A study of a newly-developed precision thread grinding machine. J. OTSUKA, A. YAMAMOTO, I. YOSHIMOTO and Y. NAKANO

Performance of silicon carbide wheels in grinding tool steels. O. I. AHMED and D. S. DUGDALE

Characterisation of grinding wheel topography and wear. S. K. BHATTACHARYYA and C. G. HILL

Grinding fluid, wheel wear and surface generation. K. C. TRIPATHI and G. W. ROWE

Applications of surface integrity measurements in grinding. T. L. GUEST and 


\section{VIBRATION AND NOISE}

A study of the modal shapes of machine tool column structures. S. K. KARK,

213

Computer study of a milling machine. S. TAYLOR

Torsional vibration of machine tool drives using speed change gears. REINER BOHM and K. G. MULLER

Acoustic design for a layout of a manufacturing area. G. J. MCNULTY and G. ROSENHOUSE

Machinery noise: the user's viewpoint. M. F. RUSSELL and S. P. MAY

Research on noise generated in impact forming machines at the University of Birmingham, 1971-1976. M. M. SADEK and S. A. TOBIAS

\section{EDM, ECM AND LASERS}

A large increase in cutting rate by using a dielectric under static pressure. C. N. LARSSON and SING-HON WONG

Dynamic effects of the dielectric fluid in electro-discharge machining. P. W. WELLS and P. C. T. WILLEY

An analysis of debris from the electro-discharge machining process and the conclusions to be drawn about the physical processes of metal removal. P. C. T. WILLEY

The performance of single-electrode fine-hole drilling by electro-discharge machining. J. R. CROOKALL and M. I. KAMAL

Some practical and theoretical aspects of a modified ECM process with stationary electrodes. D. GRAHAM

New ultra-high speed photographing system with giant-pulse ruby laser. MASAYUKI IKEDA, SHINEI MINETA and OSAMU IMANAKA

Laser machining and fabrication - a review. BRIAN F. SCOTT

\section{HOT FORMING}

The accuracy of forging load estimation in drop forging. A. THOMAS and I. BANNISTER

The oxidation of steel at high temperatures and its effect on die surface temperatures in hot forging. M. A. KELLOW, T. A. DEAN and the late F. K. BANNISTER

Load and 'rise'; their dependence on flash geometry and machine characteristics in drop forging. T. A. DEAN

Hot workability of mechanically alloyed In-738. GERNOT H. GESSINGER, LARS HELLNER and HANS JOHANSSON

Thermoplastic gears formed in the solid-state. T. A. DEAN and C. R. ANDERTON

\section{EXTRUSION}

On load pressure requirements during the cold extrusion of composite materials. C. HOLLOWAY, M. B. BASSETT and T. SHEPPARD

Assessment of lubrication for the cold extrusion of steel. N. A. ABDUL

On the pressure required for extrusion of shaped aluminium sections. T. SHEPPARD and E. P. WOOD

Investigations into continuous extrusion. B. LENGYEL and SEPEHR KAMYABTEHRANI

Strain and pressure distribution in extrusion containers. B. LENGYAL and J. K. MUSUVA

A class of slip-line field solutions for unsymmetrical extrusion and some experimental results. N. R. CHITKARA, N. S. DEAN and W. JOHNSON

Flow through conical converging dies with hydro dynamic lubrication treated as an adiabatic process. BETZALEL AVITZUR

\section{EXTRUSION, DRAWING AND COMPACTION}

A study of clamps for semi-continuous extrusion. M. E. SAID and J. M. ALEXANDER

Further investigation of the process of cold plug drawing of implosively welded bimetallic tubes. S. TOWNLEY/and T. Z. BLAZYNSKI

Determination of the mean coefficient of friction in the direct drawing of section rods from round bars. B. B. BASILY and D. H. SANSOME 
A comparison of slow speed, high speed and multi-blow compaction in ferrous powders.

R. DAVIES and S. ELWAKIL

Material behaviour and limits of cracking in powder preform forging. M. NEGM and R. DAVIES

The powder metallurgy, dynamic and quasistatic, of stainless steel scrap turnings. DEREK RAYBOULD

\section{SPINNING, ROLLING AND CROPPING}

An investigation into power assisted metal spinning. A. YOUNGER and A. J. FOSTER

Spin-forging of sheet metal cones having various cone angles and an upper bound estimate for the tangential component force exerted at the workpiece-roller interface. R. A. C. SLATER and A. JOORABCHIAN

An experimental study of the spin-forging of sheet metal cones using a mandrel of constant cone angle. R. A. C. SLATER and A. JOORABCHIAN

Observations on the mode of deformation during aluminium slab rolling. D. S. WRIGHT and T. SHEPPARD

Tube cropping with a floating mandrel. TAKEO NAKAGAWA and KIYOSHI SUZUKI

\section{EXPLOSIVE FORMING AND FUNDAMENTAL ASPECTS OF FORGING}

Surface roughness of electrohydraulically formed tubes. YOSHINORI NAKAZAWA, SHIRO YAJI and HIROSHI KAGA

Explosive forming and punching T316 stainless steel tubes, a case history. THAD A. PEAKE and RICHARD P. GROLLO

Design of tooling for compressing a cylindrical billet with consideration to tolerance specifications on the billet diameter. L. E. FARMER

Instability modes in deep-drawing. P. NG, J. CHAKRABARTY and P. B. MELLOR

A plasto-hydrodynamic analysis of high speed disc forging. P. J. THOMPSON and G. R. SYMMONS

The effect of friction in simple upsetting of cylindrical billets of elastic-plastic and elastic-strain hardening material: a numerical technique. M. S. J. HASHMI and F. B. KLEMZ

\section{DEFECTS IN METAL WORKING PROCESSES AND PEEN FORMING}

A survey of some physical defects arising in metal working processes. W. JOHNSON and A. G. MAMALIS

An investigation into the effect of the geometric factors on the closure of holes during flat rolling. M. A. CHAABAN and A. HELMI

A study of the closure of cavities in swing forging. M. A. CHAABAN and J. M. ALEXANDER

Recent Japanese work on peen forming. Y. MIHARA and W. JOHNSON

Some factors in the shot-peening and peen-forming processes. S. A. MEGUID, W. JOHNSON and S. T. S. AL-HASSANI 


\section{OPENING ADDRESS}

PROFESSOR SIR SAM EDWARDS, F. R. S.

Chairman, Science Research Council

It gives me great pleasure to give the opening address to this meeting, particularly as the meeting is being held here in Birmingham which houses one of our leading engineering schools and in particular the excellent Department of Mechanical Engineering headed by Professor Tobias.

Here in Britain, like most nations whose prosperity depends on technology, we are faced with difficult problems concerned with the balance between employment and technical efficiency. Britain has heavy unemployment at present, as have many countries in the present economic depression, but it is clear that the unemployment Britain has is very much smaller than the unemployment it would have if many of its industries ran at the optimum level of other countries. Many British industries are capable of direct comparison with industries abroad and it is quite clear that there is an urgent need for the modernisation of British industrial plant to remain competitive. If such modernisation takes place, and indeed it must take place for Britain to survive, it does imply a very changed pattern of employment in the next decade and the decade after that. Such a modernisation inevitably leads to further automation and to further reduction of the labour force. Thus if Britain takes full advantage of the new equipment becoming available, and indeed available at the present time, it will apparently need a quite different balance in the skills and deployment of its population in the coming years. Any nation in our position is therefore faced with two competing problems. Firstly the need to use less labour if its factories are to remain competitive, and secondly, to use more labour in some way to avoid the blight of a vast population of unemployed. A general solution to this problem is by an increase in the wealth of the country, i. e. a general expansion whereby many more plants are needed and many more jobs are created. Thus our Government very rightly is placing its major emphasis on the creation of wealth in the country. However it is rather worrying to note that there is not as yet any overall manpower planning in this country and indeed many politicians, not only those on the right of the political-spectrum but also on the left, have a great disbelief in manpower and industrial planning. The reason for this is that it has been attempted in the past and very often has been quite hopelessly wrong. This in itself is no reason why one should not look into the future, and one thing seems quite clear in the light of the latest research by social scientists and that is that previous attempts at manpower planning were really woefully inadequate. It follows therefore that governments all over the world should be trying to work out on the basis of some guesses about the world's prosperity in the 1980's what kind of industrial output their nation should have and what kind of manpower would be required. All this discussion may seem a little bit far away from machine tools, but in fact it is very closely related with the subject of this conference. If one is going to make some estimate of what the future holds one essential part of it is to appreciate just how much computers will play roles filled by human beings in the past, not only in the design of machine tools but in the entire productivity of a factory, and in order to do this, one has to know a great deal about machine tools as they are now and how they will be in the future.

Whatever the predictions of the future are, one thing seems to be quite clear. There will be an increasing need for highly skilled manpower and an increasing need for highly sophisticated machines. There can be no concordat across the world limiting the efficiency of any nation or deciding that there will be some restriction on the output of highly skilled engineers rather in the way there are occasional attempts to limit armed forces. This means that those of us in the educational system have a fairly easy remit particularly since we need in the first instance only to respond to the future of the next five or ten years. In Britain this picture is depressingly clear. The number of students coming forward from schools who wish to be trained as engineers is continually decreasing. The demand from industry is continually increasing. It follows therefore that there will be an increasing debate in Britain as to whether we are producing the right number of the right people.

Britain has a very large higher educational system with universities and polytechnics and technical colleges, the whole cost of which cannot be much short of a thousand million pounds a year. If a system on this grand scale cannot produce the kind of people the nation wants there must be something very much wrong with it. If we look at the pattern of young people coming forward for higher education there seems to be a fairly distinct progression. They divide first of all 
into two halves; the first half of those people who for some reason have given up mathematics and science early on in their school career and to all intents and purposes are then lost to our particular world. Then there are those who could do engineering in the universities but their education is dominated by a kind of pecking order in which medicine appears at the one end and production engineering at the other. In many ways this is entirely the wrong way round.

Production engineering gives the wherewithal for the nation's wealth. Medicine consumes wealth in the grandest manner. Of course, saying that, we are all very grateful for the help the medical profession gives us, particularly in this country where there is a very efficient national health system, but it nevertheless means that we have a spectrum of disciplines where we appear to have far too many biologists, rather too many physicists, a moderate surplus of chemists, too few engineers in general and a deplorable lack of production engineers at the bottom of the heap.

What can be done about this situation? For the first class of people it is very hard to see what we can do. The reorganisation of the schools in Britain, although it may be an excellent thing from the point of view of social justice, is likely to reduce the number of people capable of an engineering education simply because the number of schools taking would-be engineers has increased far faster than the number of competent mathematics and science teachers. This is a very elementary non-political point but the fact is that it is one that no-one ever seems to discuss. If we turn to those people who are educated in the sciences, we are faced with a real problem, not necessarily restricted to Britain at all, of persuading people to do subjects which are useful. The liberal trends in universities, by which people can mix subjects, have entirely the wrong effect. It is quite easy to leave technical disciplines and move towards arts and socialogical subjects. It is impossible to move the other way. So the liberating influences within universities, however splendid their aspirations, always tend to decrease the number of technically skilled people turned out at the other end. My only contribution to this debate would be to suggest that we should go back to something like the old state scholarship system and provide altogether better financial terms for people undertaking the kind of education which is to the national good, perhaps something along the lines of the Grandes Ecoles system in France. However I am the Chairman of the Science Research Council, and the Council has responsibility for one small part of the educational system, which although small in numbers, is perhaps considerably more significant when it comes to the final effect.

The Science Research Council has the responsibility to place graduate students on suitable courses for Masters and Doctors degrees and to support and monitor their progress. In doing this task we look with considerable envy at our colleagues in continental Europe whose role is understood, appreciated and strongly supported by their industries. Here in Britain, the attitude of industry to the advanced training of engineers is ambiguous. On the one hand, the long and successful training given on the Continent is recognised in its excellence. On the other hand, industries dream of the days of Imperial prosperity where individual companies with a vast captive market could and did afford to do all the advanced training themselves. We have a position in Britain where the romantic theory is that engineers after their first degree are trained in industry. The reality is that the majority of them are not trained at all. When the state attempts to come into this problem by providing courses in the universities many British industrialists, remembering their happy days in apprenticeships before or immediately after the war, object and say that is not the way to do education, but nevertheless they offer no alternative to this method.

Fortunately, a new initiative which Sir John Atwell described at the last of these conferences shows every sign of succeeding. This initiative is called the Teaching Company, an analogy with the Teaching Hospital of the medical profession. It couples university and industry in an imaginative joint teaching and research programme where university teachers and production engineers come together in designated factories to offer deep but also practical training for graduate engineers. I expect our continental colleagues will wonder why we are making such a fuss over such a step which is so obvious. Nevertheless it is a real innovation in this country and it deserves all the help that academics and industrialists can give it. The experiments that SRC and the Department of Industry have sponsored are doing well, and there is every hope of a really massive increase in the number of fully trained production engineers in Britain who can fully exploit the new discoveries that you will be hearing about in this meeting. It will mean a more organized mode of operation for the universities and polytechnics in this country, but a partnership between these institutions and industries which everyone knows is needed and which I, as the Chairman of SRC, am most happy to do my bit to encourage. 